\title{
Effect of Some Superplasticizers on the Physico- chemical Properties of the Hardened Cement Pastes
}

\author{
S.A. Abo-El-Enein, I.A. Aiad", M.A. Heikel ${ }^{* *}$ ، S.M.A. El- \\ Gamal and M. Mahmoud*** \\ Faculty of Science, Chemistry Department, Ain Shams \\ University " ${ }^{*}$ Egyptian Petroleum Research Institute, EPRI, \\ Cairo and ${ }^{* *}$ Chemistry Department, Faculty of Science, Benha \\ University, Benha, Egypt.
}

\begin{abstract}
TN THIS work the effect of prepared melamine formaldehyde sulfanilate (MFS) and cyclohexanone formaldehyde sulfonate (CFS) on the physico-chemical properties of the hardened OPC pastes was investigated. The investigation included the determination of the chemically combined water and free lime contents as well as the compressive strength of the hardened admixed cement pastes at different time intervals. Besides, the rheological behavior of the fresh cement pastes was studied. The phase composition of the formed hydration products was identified by using X-ray diffraction analysis. The results showed that as the dosage of admixtures increases, the water of consistency decreases; this leads to a decrease in the initial porosity of the cement pastes, and consequently the compressive strength values increase. Also as the admixture dosage increases, the extent of adsoption on the surface of cement particles increases. This leads to an increase of the negative charge on the cement particles with strong repulsion between them and a consequent enhancement of the rheological properties of cement pastes. The results of X-ray diffraction analysis indicated that the main hydration products formed are the nearly amorphous calcium silicate hydrates (mainly as CSH-I and $\mathrm{CSH}-\mathrm{II}$ ), calcium sulphoaluminate hydrates (ettrringite and monosulphate hydrates) and portlandite $(\mathrm{CH})$.
\end{abstract}

Keywords: Ordinary portland cement, Superplasticizers, Free lime, Combined water, Compressive strength and Minislump.

Superplasticizers (high range water reducers), are chemical admixtures used where well-dispersed particle suspension is required. They are linear polymers containing sulfonic acid groups attached to the polymer backbone at regular intervals ${ }^{(1)}$. The sulfonic acid groups are responsible for neutralizing the surface charges on the cement particles and causing dispersion, thus releasing the water tied up in the cement particle agglomerations and thereafter reducing the viscosity of the paste and concrete ${ }^{(2)}$. The use of superplasticizers in concrete began in the 1960s and was a milestone in concrete technology and the field of construction. By this way the production of concrete of high performance and 
durability was achieved, because adding superplasticizers; high workability remained at a very low ratio of $w / \mathrm{c}^{(3)}$. Superplasticizers are poly-electrolytes of organic origin, used as dispersants to avoid particle segregation (gravel,coarse and fine sands), and to improve the flow characteristics (rheology) of suspensions such as in concrete applications.

Naphthalene-formaldehyde sulphonate is the most known superplasticizer. It is generally acceptable that lignosulfonic superplasticizers in high dosages result in delaying the hydration of concrete. Another group of superplasticizers are based in sulfonated products of synthetic polymers (e.g. SNF, naphthalene or SMF, melamine). These materials result in a higher decrease of required mixing water and so higher strengths are obtained. The family of superplasticizers which are based in polycarboxylic products is known since 1980s. These compounds are of higher reactivity and they are totally ionized in alkaline environment.The superplasticizers of high reactivity, which in high dosages do not cause delaying the curing of concrete,made the production of concrete with a big volume of fly ash or slag possible ${ }^{(4)}$. Superplasticizers causes increase the workability of a mixture very much, but this increase is not retained for more than 30-60 min. However for retaining the workability for longer time various ways can be used (addition of admixtures during the placement or in doses).Also, it is found that the type of the admixture affect the loss of slump of concrete ${ }^{(5,6)}$. The ability of superplasticizers to increase the slump of concrete depends on many factors such as the type, dosage, and time of addition of superplasticizer; w/c; and the nature or amount of cement. It has been found that for most types of cement, superplasticizer improves the workability of concrete ${ }^{(7,8)}$. Various studies have been published that deal with the effect of addition of superplasticizer on the physicochemical properties of ordinary Portland cement pastes ${ }^{(9)}$.

The main purpose of using superplasticizers is to produce flowing concrete with very high slump in the range of 7-9 inches $(175-225 \mathrm{~mm})$ to be used in heavily reinforced structures and in placements where adequate consolidation by vibration cannot be readily achieved. The other major application is the production of high-strength concrete at w/c's ranging from 0.3 to $0.4^{(10)}$. The capability of superplasticizers to reduce water requirements $12-25 \%$ without affecting the workability leads to production of high-strength concrete and lower permeability

\section{Experimental}

Ordinary Portland cement (OPC) with a Blaine area of $2945 \mathrm{~cm}^{2} / \mathrm{g}$; was supplied from El-Sewedy Cement Company, its chemical composition is given in Table 1. Two superplasticizers were supplied from the Egyptian Petroleum Research Institute; these superplasticizers are Melamine Formaldehyde Sulphanilate (MFS) with solid content of $23 \%{ }^{(11)}$ and Cyclohexanone Formaldehyde Sulphonate (CFS) with solid content of $40 \%^{(12)}$. 
The freshly prepared cement pastes were made of the neat OPC and OPC admixed with different dosages of admixtures to give the optimum water/cement (W/C) ratio corresponding to the standard water of consistency of each paste using Vicat apparatus ${ }^{(13,14)}$.

Preparation of cement pastes was done by mixing OPC and OPC in presence of different dosages of each superplasticizers with the amount of water required for standard consistency within three minutes. The dosage percentages of the admixtures used were 0 (control OPC paste), $0.25,0.50,0.75$ and $1.00 \%$ by the weight of cement.

Freshly prepared cement pastes were introduced into one inch cubic moulds in two approximately equal layers manually compacted and pressed until homogeneous specimens were obtained. The moulds were vibrated for $3 \mathrm{~min}$ to remove any air bubbles to give a better compaction, cured in a humidity chamber at about $100 \%$ relative humidity at constant temperature of $25 \pm 1{ }^{\circ} \mathrm{C}$ for 1 day, then demoulded and immersed under tap water until the rest time, of testing $(3,7$, 28, 90 and 180 days) was reached. A set of three cubes was used for the determination of compressive strength of the hardened cement paste as described by ASTM Specifications ${ }^{(15)}$. The strength measurements were done on a using Control's compressor, manufactured in Italy.

The stopping of hydration process for all pastes was performed on the fractured parts of the specimens after compressive strength determination. This process was performed by using about 10 grams of the ground cement pastes with about $100 \mathrm{ml}$ of acetone / methanol mixture (1:1 by volume) using a magnetic stirrer for at least one hour and then the solvent mixture was removed by decantation and filtration. Finally, the solid sample was then dried at $80^{\circ} \mathrm{C}$ in the drier for overnight ${ }^{(16)}$.

The kinetics of hydration was studied by the determination of combined water and free lime contents at the different ages of hydration.The combined water content is considered as the percentage of ignition loss of the dried sample with correction regarding the free lime content. $2 \mathrm{~g}$ of the dried sample, at each hydration age was gradually ignited up to $1000^{\circ} \mathrm{C}$ for $1 \mathrm{hr}$. The combined water of the cement paste was used by Brunauer and Copeland as a measure of the degree of hydration ${ }^{(17)}$; it is also used to calculate the gel/space ratio ${ }^{(18)}$ of the hardened cement pastes made with the appropriate water of consistency for each paste using the different admixtures dosages.

The free $\mathrm{CaO}$ content was determined by the following method ${ }^{(19)}$; exactly about $0.5 \mathrm{~g}$ of the dried sample was dispersed in $40 \mathrm{ml}$ of glycerol/ethanol mixture (1: 5) by volume, together with small amount of anhydrous barium chloride (about $0.5 \mathrm{~g}$ ) as catalyst, and phenolphthalein as indicator. This mixture was kept in a conical flask, fitted with an air-reflux, on a hot plate for $30 \mathrm{~min}$ 
(the color becomes pink). The contents were titrated with a standardized alcoholic ammonium acetate solution until the pink color disappeared. Heat again, if the pink colour reappears, complete the titration with ammonium acetate solution until no further appearance of pink colour takes place.

The mini slump test consists of carrying out a slump test on a small amount of cement paste. The cement pastes were prepared at constant W/C ratio of 0.265 by different polymers dosages of $0,0.25,0.5,0.75$ and $1 \%$ by weight of cement. The cement pastes were stirred by mechanical stirrer for three minutes and rest for one minute and two minutes by the same speed, then it was poured into a stainless steel cone with the same geometry as Abram's cone for regular slump tests, but with reduced dimension (height of $60 \mathrm{~mm}$, the bottom diameter is 40 $\mathrm{mm}$ and the top diameter is $20 \mathrm{~mm}$ ). The mini-cone is put on vibrated table then it was removed vertically. After removing the filled truncated mini-cone, the material flows until reaching a steady stable state corresponding to a pancake and the diameter of the spread of the cement paste is measured ${ }^{(20)}$.

X-Ray diffraction was used to investigate the phase composition of the formed hydration products. The apparatus used was "Philips Xpert 2000, made in Holland". The sample was finely ground to pass a 200 mesh sieve. The X-ray diffraction patterns were converted to a series of lattice spacings $d(\AA)$. The relative intensities were visually estimated. The data obtained were then compared with the ASTM standard tables.

\section{Results and Discussion}

\section{Water of consistency}

The variations of required water of standard consistency, water reduction of the cement pastes with different dosages of MFS and CFS, are represented in Fig.1. The results show that the water/ cement ratios (W/C) for all cement pastes containing the admixtures are lower than that of control (neat OPC) paste. This is due to adsorption of these admixtures, which contains $\mathrm{SO}_{3}{ }^{-}$group, on the surface of cement grains leading to electrostatic repulsion forces between cement grains. This leads to prevention of the formation of flocculated structures and the consequent increase of the fluidity of the fresh pastes. The maximum water reduction increases as the dosage of the admixture increases, which reflects the role of these admixtures on the characteristics of the hardened cement pastes ${ }^{(.21)}$. Also, the results indicated that (MFS) has a higher water reduction than that of (CFS), as shown in Fig. 1.

\section{Compressive strength}

The compressive strength values of the hardened cement pastes made by using CFS and MFS admixtures with different dosages $0.25,0.50,0.75$ and $1.00 \%$, are graphically represented in Fig. 2 and 3, respectively.

Egypt. J. Chem. 59, No.2 (2016) 
Effect of Some Superplasticizers on the Physico-chemical Properties...

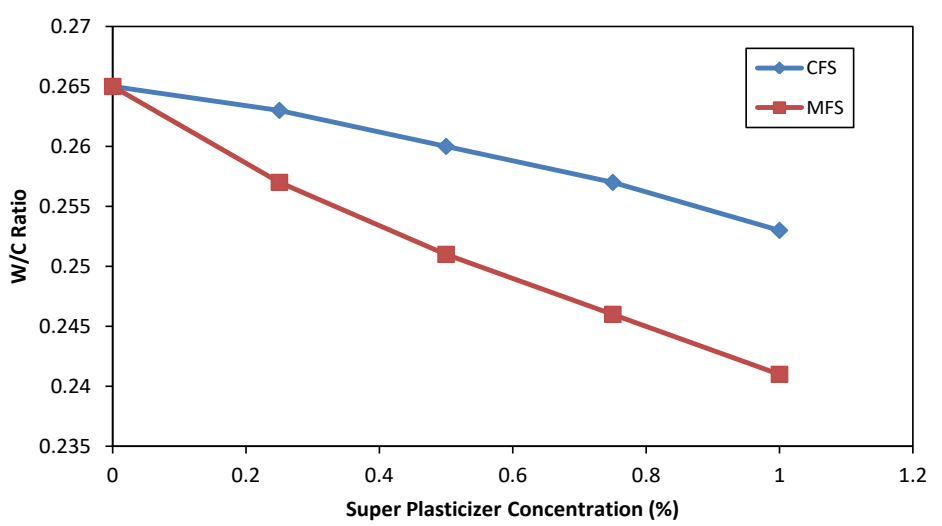

Fig. 1. Standard water of consistency.

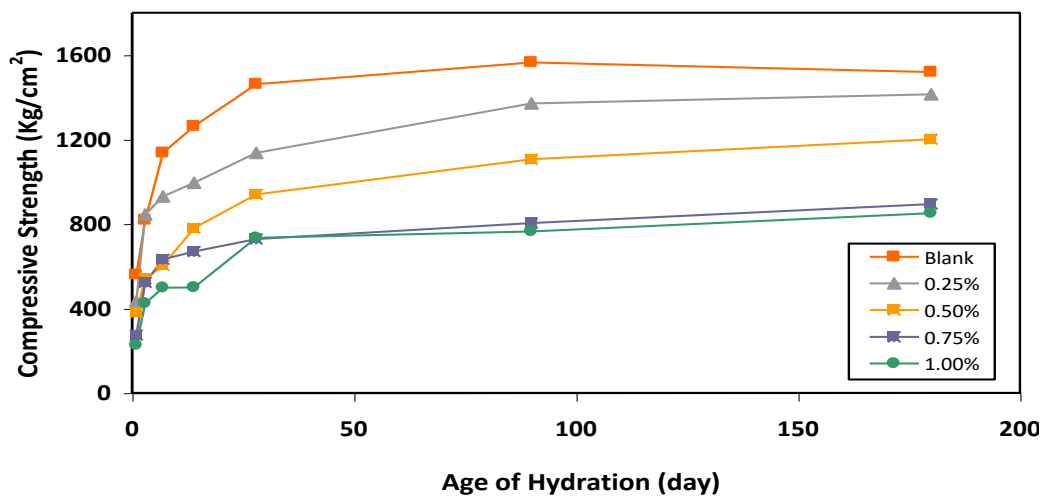

Fig. 2. The results of compressive strength versus age of hydration for the hardened neat and OPC pastes admixed with CFS.

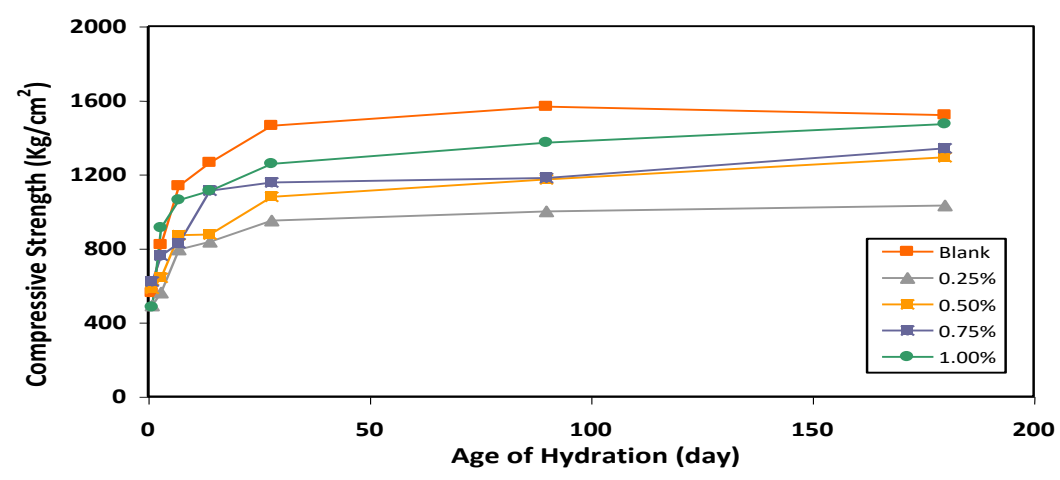

Fig. 3. The results of compressive strength values versus age of hydration for the hardened neat and OPC pastes admixed with MFS.

Egypt. J. Chem. 59, No.2 (2016) 
The results of compressive strength obtained for the hardened neat OPC paste and OPC pastes admixed with CFS superplasticizer indicate a continuous increase with increasing age of hydration, as shown in Fig. 2. This increase is attributed to the hydration of OPC and the formation of hydration products (mainly as CSH) having strong hydraulic character and act as binding centers between the remaining unhydrated parts of cement grains. Evidently; the obtained results revealed that; all the admixed OPC hardened pastes showed lower compressive strength values comparing to that of neat OPC(blank) and increasing the percentage of CFS additions leads to a more notable decrease in the compressive strength values at all the ages of hydration. The indication gained from these results is that CFS superplasticizer acts as retarder beside its water reducing effect.

The compressive strength values of the neat OPC hardened paste and OPC hardened pastes admixed with different amounts of MFS are shown in Fig. 3. Obviously, a continuous gradual increase in the compressive strength values up to the final age of hydration (180 days) was obtained for all mixes. This increase in the compressive strength values is explained in terms of the initial formation and later accumulation of hydration products in the pore system of the hardened pastes (mainly as CSH) leading to decrease the total porosity and increase the total contents of binding centers in the hardened specimens: these two factors operate in the same direction and lead finally to a continuous increase in compressive strength with increasing age of hydration. Also, the obtained results indicated that all the MFS admixed OPC pastes have lower compressive strength values as compared to blank, and as the percentage additions of MFS increase a more notable increase in the values of compressive strength was observed during nearly all ages of hydration (Fig. 3). This increase is attributed to the decrease in the values of standard water of consistency, which causes a decrease in the total porosity of the hardened pastes, leading to increase the compressive strength values.

\section{Kinetics of hydration}

Combined water content

As shown in Fig. 4 and 5, the results of chemically combined (nonevaporable) water contents obtained for neat OPC, CFS and MFS superplasticed OPC pastes indicate a gradual continuous increase with increasing age of hydration up to the final age of hydration (180 days). This increase is attributed to the progress of hydration reaction. In addition, the increase in the amount added of CFS and MFS causes a more notable decrease in the values of the combined water contents. This decrease is attributed to the decrease in the values of standard water of consistency by increasing the amounts of CFS and MFS. Finally, the results revealed that, all the admixed hardened specimens showed lower values of combined water as compared to the blank hardened cement specimens.

Egypt. J. Chem. 59, No.2 (2016) 


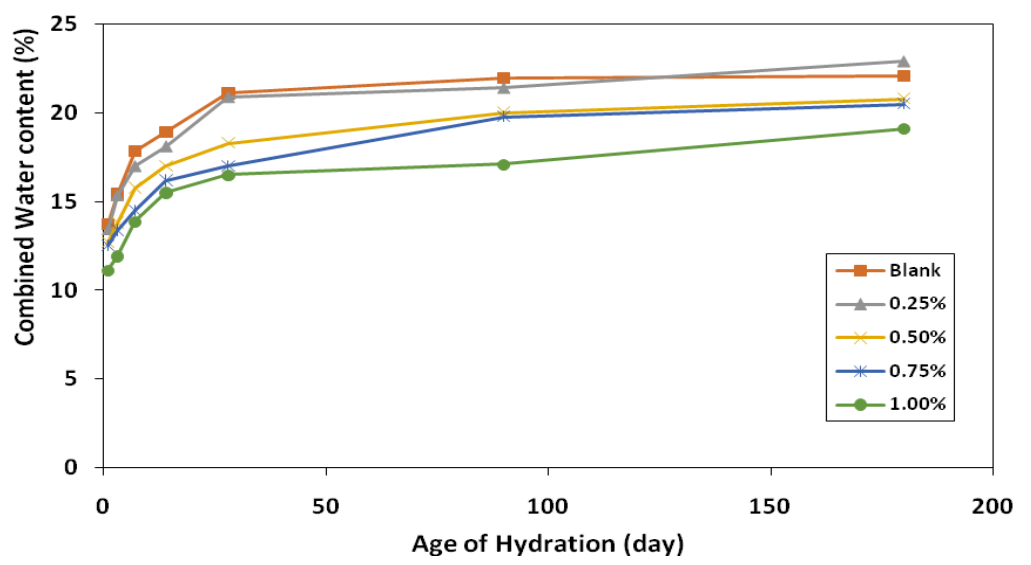

Fig. 4. The results of combined water contents versus age of hydration for the neat and CFS admixed OPC hardened pastes with CFS.

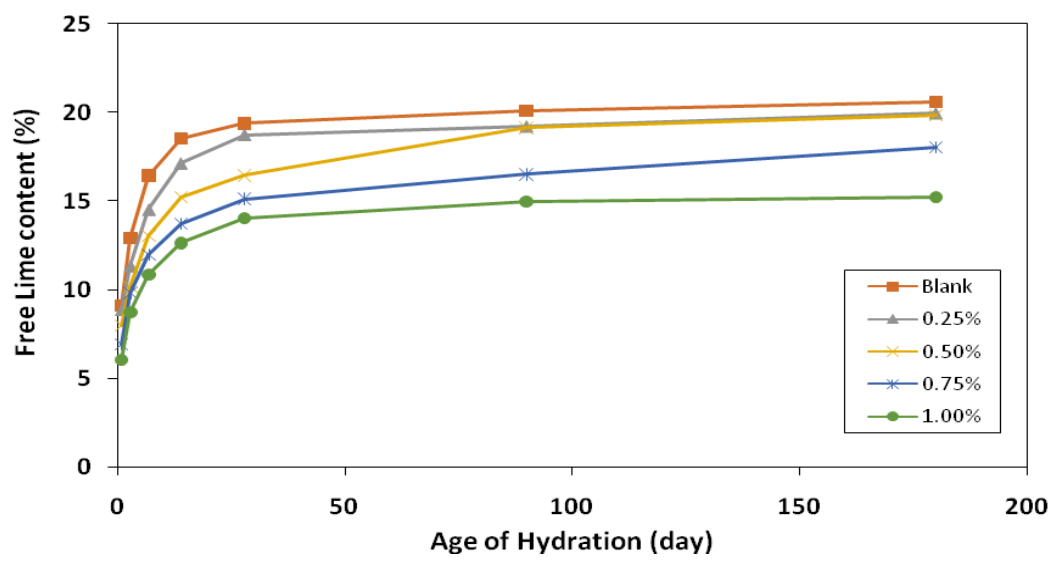

Fig. 5. The results of combined water contents versus age of hydration for the neat and admixed OPC hardened pastes with MFS .

Free lime contents

The results of free lime contents obtained for the neat OPC hardened paste and OPC hardened pastes admixed with different amounts of CFS and MFS are shown in Fig. 6 and 7, respectively. Evidently, the free lime contents of all hardened specimens indicate a continuous increase with increasing the age of hydration up to 180 days of hydration. This increase is attributed to the progress of OPC hydration. In addition the free lime contents obtained for the OPC hardened pastes admixed with different amonts of CFS and MFS are lower than those of the neat OPC pastes during all ages of hydration. This effect is mainly attributed to the decrease in the rate of hydration of OPC.

Egypt. J. Chem. 59, No.2 (2016) 


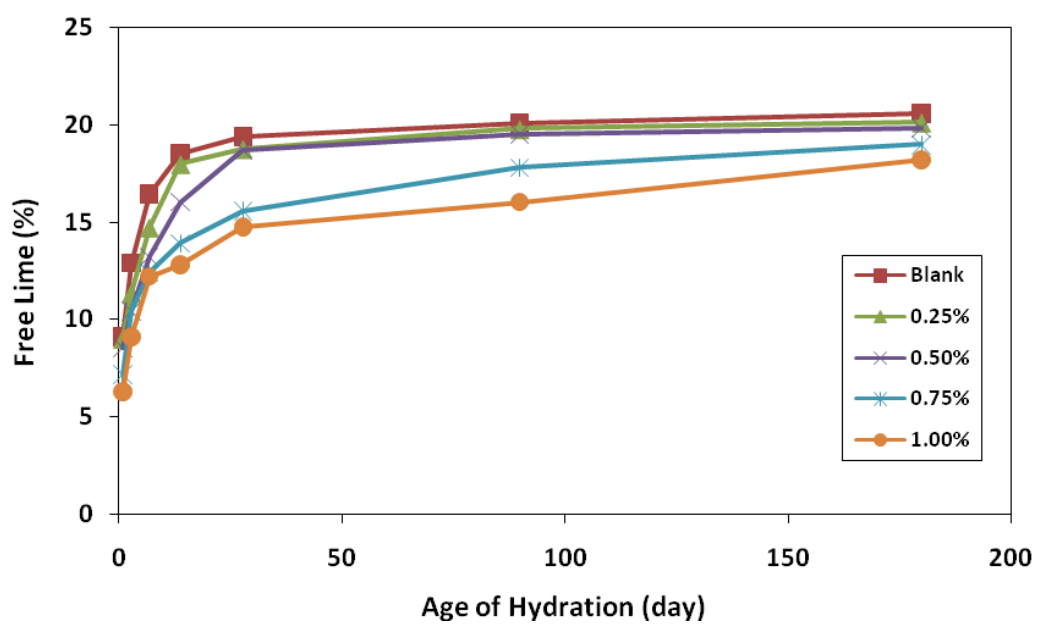

Fig. 6. The results of free lime contents versus age of hydration for the neat and admixed OPC hardened pastes with CFS.

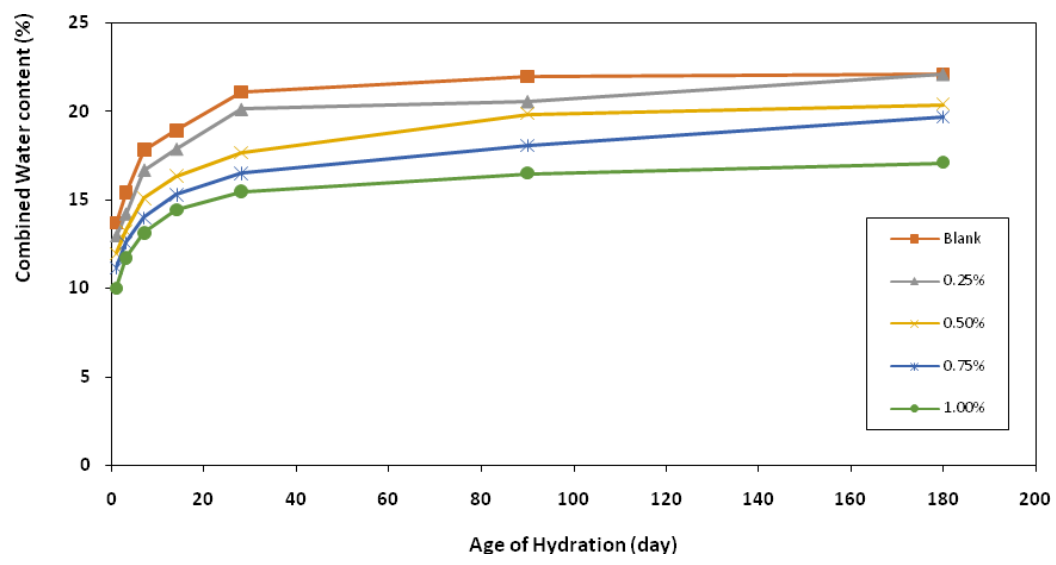

Fig. 7. The results of free lime contents versus age of hydration for the neat and admixed OPC hardened pastes with MFS.

\section{XRD Results}

The results of X-ray diffraction analysis obtained for the neat OPC paste and the OPC hardend pastes admixed with CFS and MFS are shown in Fig. 8-12. Obviously, the XRD diffractograms indicate almost the same phases for both of OPC and OPC superplasticized pastes with nearly the same behavior with increasing age of hydration (Fig. 8-12). These results are explained in terms of the fact that both MFS and CFS did not affect the type of hydration products formed, they may only affect their physical state and degree of crystallinity ${ }^{(22)}$.

Egypt. J. Chem. 59, No.2 (2016) 
Effect of Some Superplasticizers on the Physico-chemical Properties...

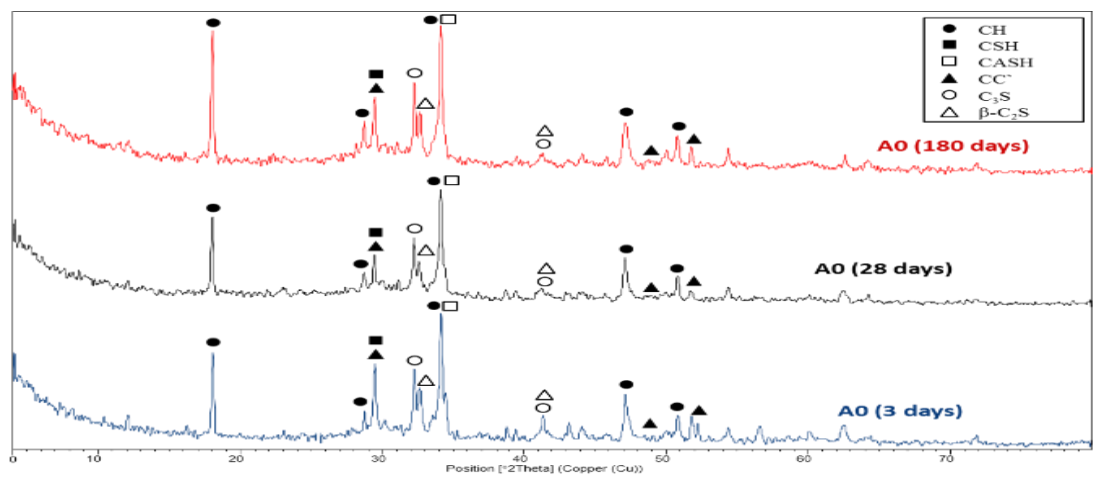

Fig.8. XRD patterns of hardened specimens made of blank sample at different ages of hydration.

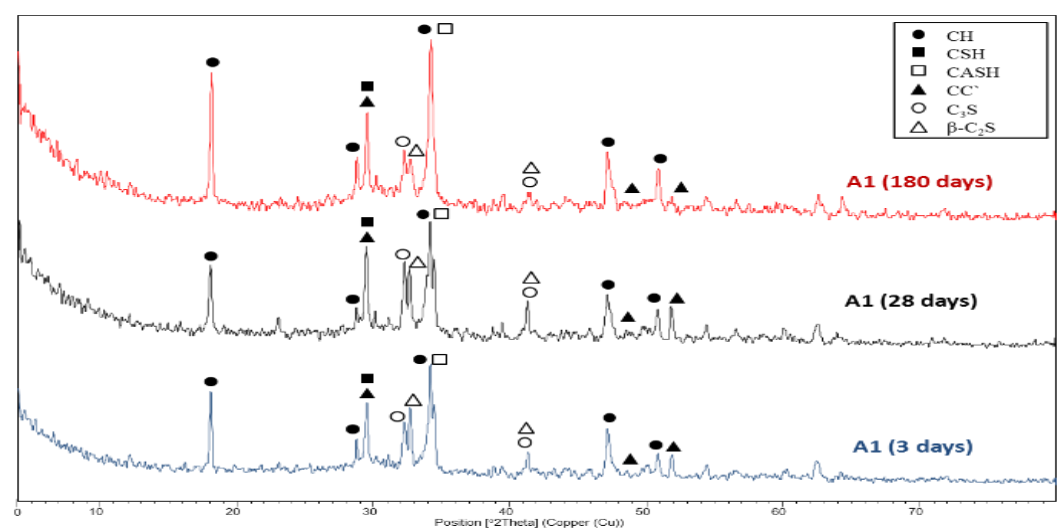

Fig.9. XRD patterns of hardened OPC specimens containing $0.25 \%$ MFS at different ages of hydration.

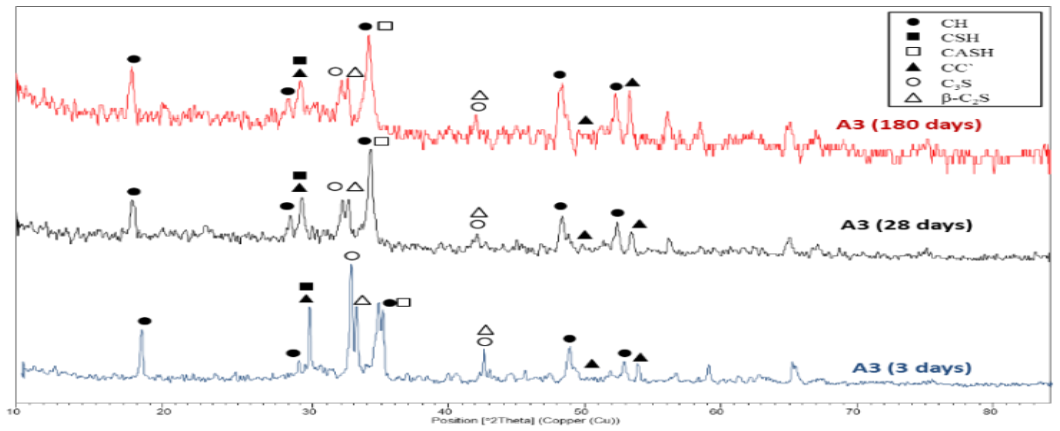

Fig.10. XRD patterns of hardened OPC specimens containing 0.75\% MFS at different ages of hydration. 


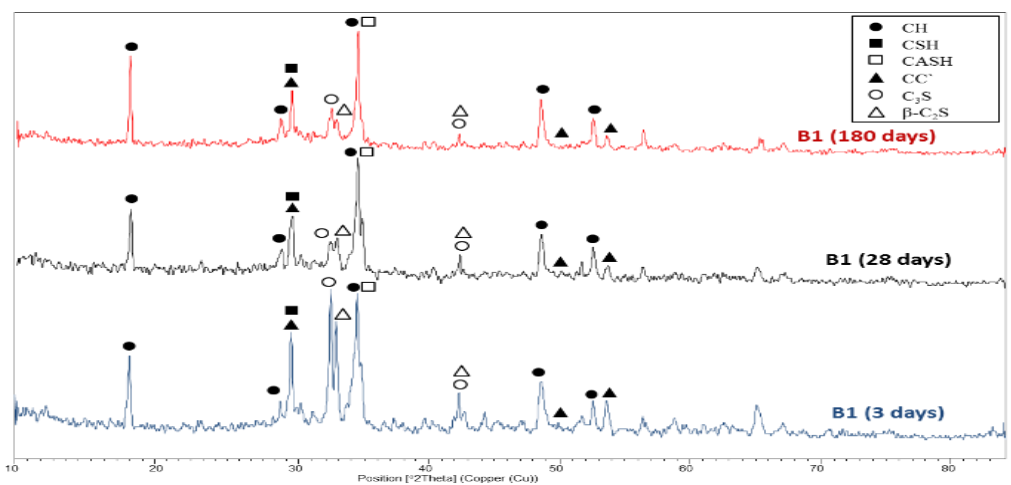

Fig.11. XRD patterns of hardened specimens containing $0.25 \%$ CFS at different ages of hydration.

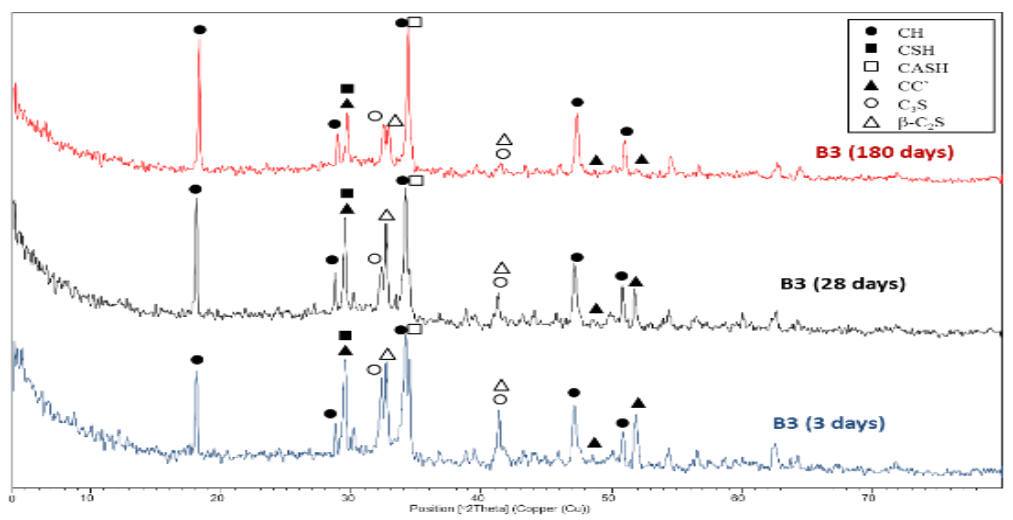

Fig.12. XRD patterns of hardened specimens containing $0.75 \%$ CFS at different ages of hydration.

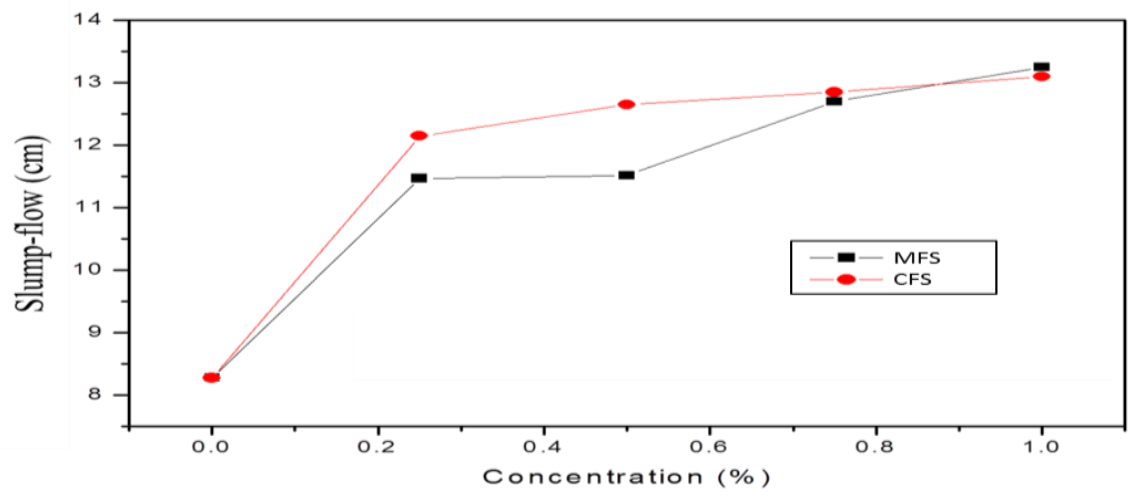

Fig. 13. The mini- slump values of the cement pastes admixed with MFS and CFS.

Egypt. J. Chem. 59, No.2 (2016) 


\section{Rheological Properities}

The rheological properties of OPC pastes were investigated by measuring the mini- slump of the OPC cement pastes. The results showed that the mini-slump values for all admixed OPC pastes are higher than amounts of that of the neat OPC paste (blank); the increase in the additions of admixture (CFS or MFS) is accompanied by a consequent increase in the values of mini-slump of superplasticized OPC pastes. The previous results are mainly attributed to the notable increase in the degree of fluidity of OPC pastes by increasing admixtures additions ${ }^{(22)}$.

\section{Conclusion}

On the basis of the results obtained in this investigation, the following conclusions can be derived:

- The results of compressive strength values of superplasticized cement pastes indicate notable lower values as compared to the values obtained for the neat OPC (blank), especially during the early ages of hydration. These results are explained in terms of the retardation effect of both MFS and CFS.

- The chemically combined water and free lime contents for all admixed hardened OPC pastes are lower than those obtained for neat OPC hardened pastes.

- Rheological measurements indicated that the mini-slump values of cement pastes admixed with different doses of CFS and MFS are higher than that of neat OPC. Also, the increase of the amount added of each admixture resulted in an increase in the values of mini-slump. These results are mainly due to increase in the fluidity of admixed cement pastes.

- The mini-slump results indicated that CFS admixture has higher efficiency in improving the rheological properties of OPC pastes as compared to MFS admixture.

- XRD difractograms obtained for neat and admixed OPC pastes indicate the formation of: nearly amorphous and illcrystalline calcium silicate hydrates (mainly as CSH-I and CSH-II), calcium sulphoaluminate hydrates (monosulphate hydrates), calcium aluminate hydrates (mainly as $\mathrm{C}_{4} \mathrm{AH}_{13}$ ), hydrogarnet (mainly as $\mathrm{C}_{3} \mathrm{ASH}_{4}$ and $\mathrm{C}_{2} \mathrm{ASH}_{8}$ ), Portlandite $(\mathrm{CH})$ and $\mathrm{CaCO}_{3}$.

TABLE 1. Chemical compositions of ordinary Portland cement.

\begin{tabular}{|c|c|}
\hline Oxide & Weight (\%) \\
\hline $\mathrm{SiO}_{2}$ & 20.32 \\
$\mathrm{Al}_{2} \mathrm{O}_{3}$ & 4.44 \\
$\mathrm{Fe}_{2} \mathrm{O}_{3}$ & 3.62 \\
$\mathrm{CaO}$ & 60.60 \\
$\mathrm{MgO}$ & 0.87 \\
$\mathrm{SO}_{3}$ & 2.33 \\
$\mathrm{Na}_{2} \mathrm{O}$ & 0.45 \\
$\mathrm{~K}_{2} \mathrm{O}$ & 1.10 \\
Insoluble residue & 2.44 \\
Loss in ignition & 3.83 \\
\hline
\end{tabular}




\section{References}

1. Verbeck, G.J., Field and laboratory studies of the sulfate resistance of concrete. In : Performance of Concrete Resistance of Concrete to Sulfate and Other Environmental Conditions: Thorvaldson symposium, 113-24. Toronto: University of Toronto Press (1968).

2. Mindess, S., Kwan, A.K.H. and Fung, W.W.S., Effects of SP on flowability and cohesiveness of cement-sand mortar. Construction and Building Materials, 48, 1050 1057 (2013).

3. Papayianni, I., Tsohos, G., Oikonomou, N. and Mavria, P., Influence of superplasticizer type and mix design parameters onthe performance of them in concrete mixtures. Cement \& Concrete Composites, 27, 217-222 (2005).

4. Langley, W.S., Carette, G.G. and Malhotra, V.M., Structure concrete incorporating high volume of ASTM class F fly ash. ACI Mater J. 86, 507-14 (1989).

5. Mailvaganam, N.P., Slump Loss in Flowing Concrete. ACI SF62. In: Malhotra VM, editor, pp. 389-404 (1979).

6. Collepardi, M., Corradi, M. and Valente, M., Low-slump loss superplasticizer concrete. Transportation Research Record 720, Washington, DC (1979).

7. Ramachandran, V.S. and Malhotra, V.M., Superplasticizers. In : Concrete Admixtures Handbook : Properties, Science, and Technology, (Ed.) V.S. Ramachandran, 211-68. Park Ridge, N.J.: Noyes Publications (1984).

8. Aiad, I., Abd El-Aleem, S. and El-Didamony, H., Effect of delaying addition of some concrete admixtures on the rheological properties of cement pastes. Cement and Concrete Research, 32, 1839-1843 (2002).

9. Emoto, T. and Bier, T.A., Rheological behavior as influenced by plasticizers and hydration kinetics. Cement Concrete Res. 37 (5), 647-54 (2007).

10. Macias, A. and Gon, I.S., Characterization of admixture as plasticizer or superplasticizer by deflocculation test. ACI Mater J. 96 (1), 40-6 (1999).

11. Phan, T., Chaouche, H.M. and Moranville, M., Influence of organic admixtures on the rheological behavior of cement pastes. Cement and Concrete Research, 36, 1807-1813 (2006).

12. Albrecht, G., Weichmann, J., Eibl, L., Huber, C. and Kern, A., Water-soluble polcondensation products based on amino-s-triazines and the use thereof. US Patent, 5, 750, 634 (1998).

13. Lei, L. and Plank, J., Synthesis, working mechanism and effectiveness of a novel cycloaliphatic superplasticizer for concrete. Cement and Concrete Research, 42, 118123 (2012).

14. ASTM standards, standard test method for normal consistency of hydraulic cement. ASTM C, 195,187-92 (2008).

Egypt. J. Chem. 59, No.2 (2016) 
15. ASTM Designation, C-150 (2007).

16. El-Didamony, H. and Khalil, A.S., Studies on artificial pozzolanic cement: physicochemical properties. Zement-Kalk-Gips, 34 (6), 312-314 (1981).

17. Brunauer, S. and Capeland, L.E., The chemistry of concrete. Scient. Am. 83, 210 (1964).

18. Neville, A.M., "Properties of Concrete", PITMAN Books limited, London, 275 (1981).

19. Abo El Enein, S.A., Daimon, M., Ohsawa, S. and Kondo, R., Hydration of low porosity slag-lime pastes. Cement Concrete Res, 4 (2), 299-312 (1974).

20. Aiad, I., Morsy, M.S. and Habib, A.O., Influence of some low formaldehyde superplasticizers on the rheological and mechanical properties of cement pastes. Journal of Silicates Industrial, 73, 71- 76 (2008).

21. Heikal, M., Aiad, I., Shoaib, M.M. and El-Didamony, H., Physico-chemical characteristics of some polymer cement composites. Materials Chemistry and Physics, 71, 76-83 (2001).

22. El-Gamal, S.M.A., Fawzia, M., Al-Nowaiser and Al-Baity, A.O., Effect of superplasticizers on the hydration kinetic and mechanical properties of Portland cement pastes. Journal of Advanced Research, 3, 119-124 (2011).

(Received 4/1/2016;

accepted 12/1/2016) 


\section{تاثير بعض المواد فائقة اللاونة على الخواص الفيزيقوكيميائية على الإئ عجائن الاسمنت المتصلدة دأسن \\ صلاح عبد الغنى ابو العينين ، اسماعيل عبد الرحمن عياد" ، محمد احمد هيكل** ، معل

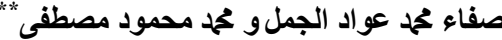

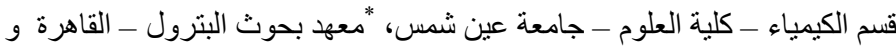

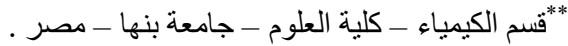

في هذا البحث تم دراسة تاثير الميلامين فورمالدهيد سلفانيلات و السيكلو هيكسانون فورمالدهيد سلفونات المحضران معمليا على الخواص الفيزيقوكيميائية لعجائن الاسمنت البورتلاندى العادى المتصلدة ، وفى هذه الدراسة تم تعيين محتوى الماء

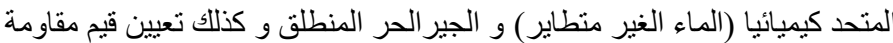
الانضغاط و هذا بالاضافة الى الخواص الريولوجية. و نم تعيين نواتج التادرت باستخدام تقنية حيود الاشعة السينية.

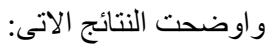

بزيادة تركيز المــواد فائقة اللاونــة فى عينـات الاسمنتنقل كمية المياه القياسية

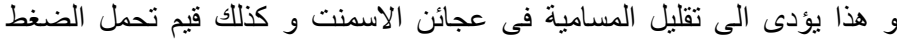

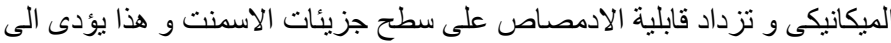

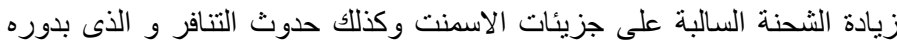
يحسن الخو اص الريولونية.

نتائج حيود الاشعة السينية توضح ان نواتج التهدرت الاساسية هى سليكات الكالسيوم المتادرتة ، السلفو الومينات الكالسيوم المتادرتة و كذلك البورتنانديت. 


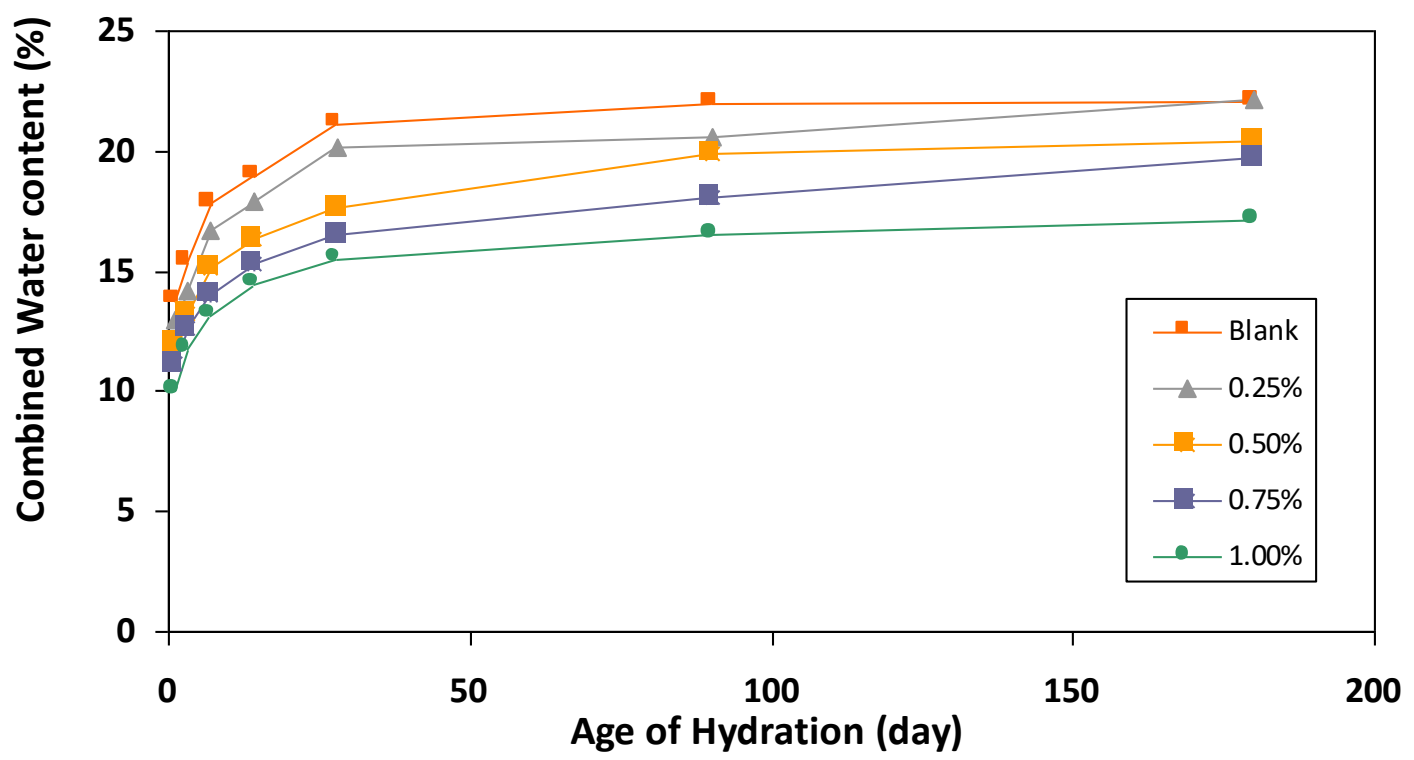


S.A. Abo-El-Enein et al.

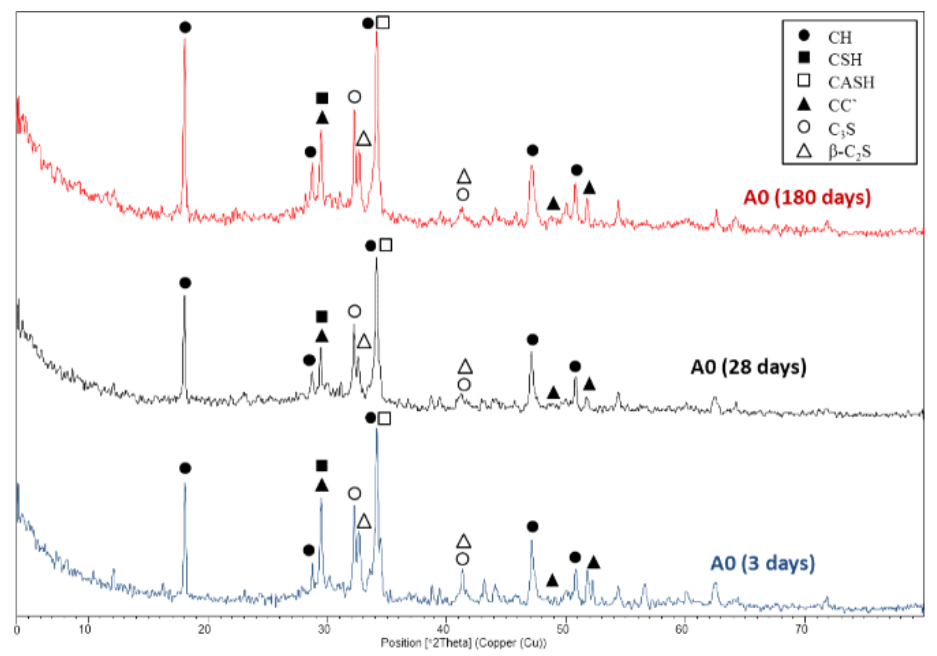

Egypt. J. Chem. 59, No.2 (2016) 
Effect of Some Superplasticizers on the Physico-chemical Properties...

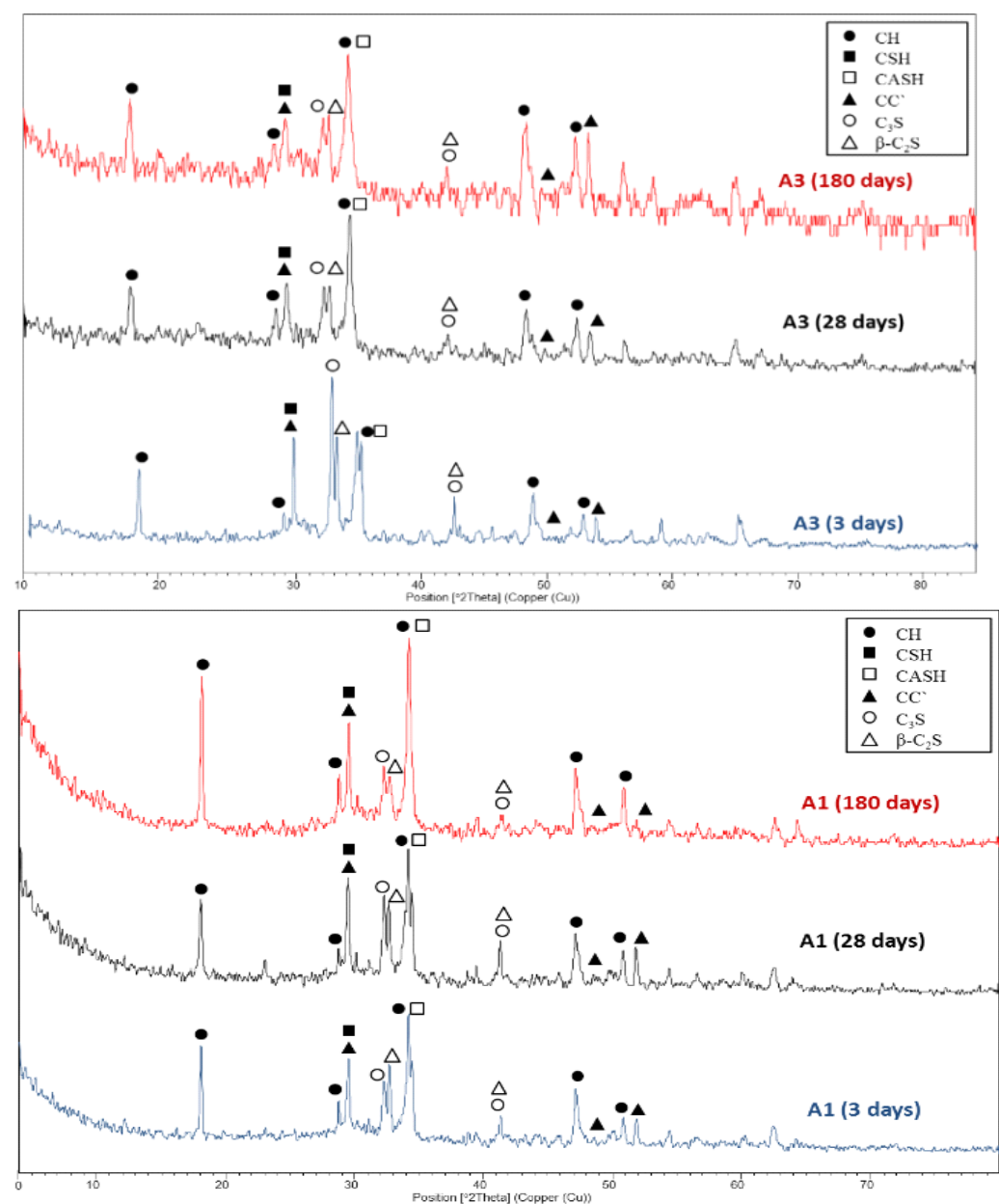

Egypt. J. Chem. 59, No.2 (2016) 
S.A. Abo-El-Enein et al.

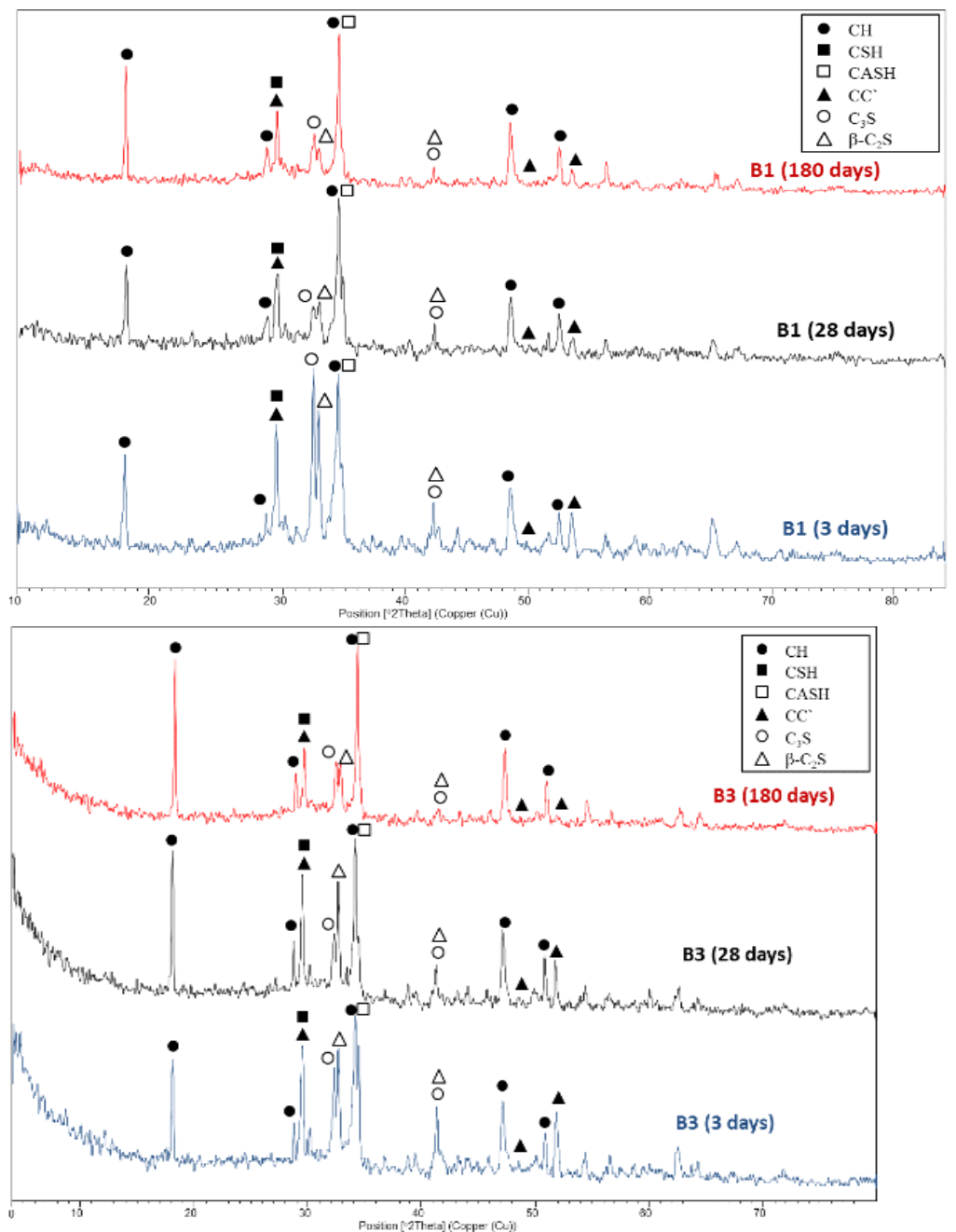

Egypt. J. Chem. 59, No.2 (2016) 


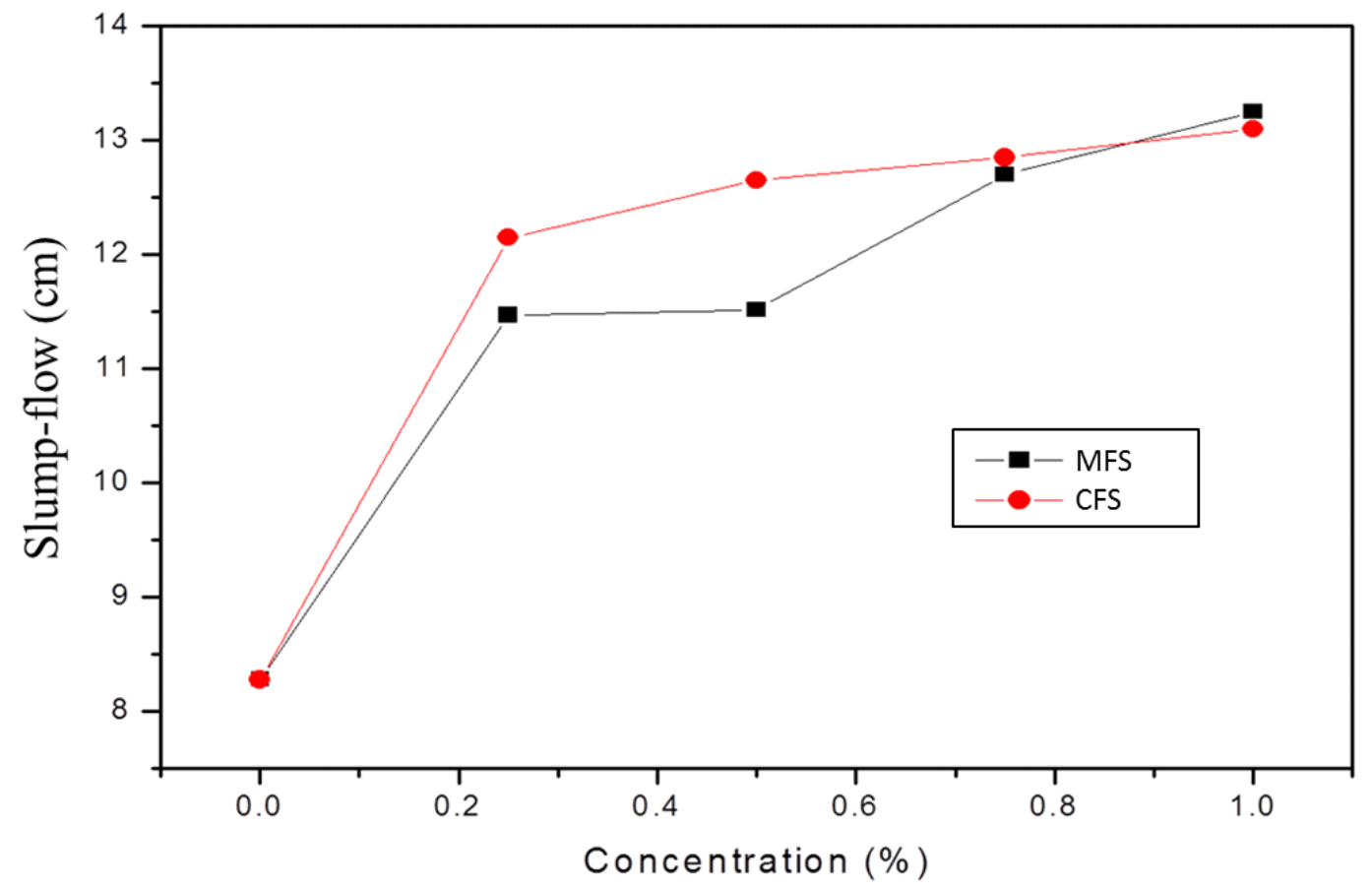

Fig. (13): The mini- slump values of the cement pastes admixed with MFS and CFS 